\title{
Green Computing in the Desert: Applying Problem- Based Learning at an Emirati University
}

\author{
John Beachboard \\ Zayed University, \\ United Arab Emirates
}

beach@isu.edu

\author{
Martine Beachboard \\ Idaho State University, \\ Pocatello, ID, USA
}

beacmart@isu.edu

\begin{abstract}
The discovery of oil along the Arabian Gulf in the 1950s brought rapid changes to Emirati standards of living and expectations. It also brought decades of expatriate labor. Today the call is for local citizens to enter private enterprise and take charge of their personal and national economics. This initiative demands higher education and higher-order thinking. The authors of this preliminary innovations-in-practice essay report on their recent use of problem-based learning in a Middle East university class on green computing. Their aim is to discover how PBL might facilitate critical thinking, self-directed learning, and motivation to assess challenges and solve problems skills that should well serve a fast-developing nation. While initial feedback from students has been very positive, the authors continue to collect and analyze student feedback. Upon completion of this data collection and analysis, a more complete report on this effort will be submitted.
\end{abstract}

Keywords: problem-based learning, critical thinking, motivation, self-directed learning.

\section{Introduction}

"Sheikh Zayed bin Sultan Al Nahyan: His progressive ideas, manifested in his program of revolutionary reforms, transformed Abu Dhabi in breakneck speed from a tribal society to a modern metropolis" (CDR, 2013).

Until the 1960s the people of Arab emirates lived a modest existence in the desert along the Arabian (Persian) Gulf. Then came the discovery of vast petroleum reserves along with the wealth, comforts and subsidies that such resources can offer. Standards of living skyrocketed to embrace high-rise apartments and shopping malls, name-brand fashions and jewelry, health care services such as cosmetic orthodontia, health problems (such as lifestyle-related Type 2 diabetes), and higher education for young men - and women. Much of the dramatically improved infrastructure of the Emirates was built by the hands of imported labor to the point that Emiratis today comprise

Material published as part of this publication, either on-line or in print, is copyrighted by the Informing Science Institute. Permission to make digital or paper copy of part or all of these works for personal or classroom use is granted without fee provided that the copies are not made or distributed for profit or commercial advantage AND that copies 1) bear this notice in full and 2) give the full citation on the first page. It is permissible to abstract these works so long as credit is given. To copy in all other cases or to republish or to post on a server or to redistribute to lists requires specific permission and payment of a fee. Contact Publisher@InformingScience.org to request redistribution permission. only about 11.5 percent of the occupants of their own land.

Now there are calls for the Emiratis to run the day-to-day operations of their own country for themselves: to work in white-, gray- and pink-collar jobs that may not offer the highest pay or prestige. There are many perspectives on the issue, but in any case the country is investing in developing its citizens to compete for jobs in a global market- 
place. Here, as anywhere, increased critical thinking skills - and the motivation to apply them to challenges - should help improve the economic and the moral future of a nation.

How can we impart these abilities and values in the university classroom? This interim innovations-in-practice essay suggests that problem-based learning (PBL) can make a worthwhile contribution to the development of student critical thinking skills. While this effort is attuned to the needs of higher education in the UAE, we believe that the approach outlined below may be more generally applied. This essay does not represent ground-breaking research. It simply shares our experience and analysis with other instructors and curriculum planners interested in techniques to enhance their students' critical thinking skills. We do describe in some detail the context in which the course has been offered to allow readers to better assess its application in their unique environments.

Developing students' ability to think critically has become the ultimate objective of higher education (ACRL, 2013). The task crosses disciplinary boundaries. In spite of years of research and teaching practice, the grumbling of many employers indicates that institutions of higher education still have a long way to go. Despite increasing calls for teaching critical thinking skills, contemporary tertiary education, somewhat necessarily, remains largely content-driven.

While we have long recognized the issue and conducted some formal research in the area of developing critical or higher-order thinking skills (Beachboard \& Beachboard, 2010; Beachboard et al., 2011), the importance of this topic was forcefully brought to the first author's attention during a new-instructor orientation at Zayed University in the United Arab Emirates (UAE). The university, recognizing the challenges of teaching critical thinking, has taken strong steps to institutionalize the effort. This essay describes the primary investigator's adoption of problem-based learning (PBL) in an upper-division Green Computing course as a means of addressing university- and department-level learning objectives relating primarily to the development of critical thinking skills and information literacy.

\section{Setting the Educational Context}

A brief introduction to UAE's history and its founding father, Sheik Zayed bin Sultan Al Nahyan, helps explain the challenges and achievements of higher education in the region. In 1918 the people of Abu Dhabi made their living from fishing, pearl-diving along the Arabian Gulf Coast, herding, and limited agriculture at nearby oases. "Before 1960s, [what is now] UAE was a poor developing country, and almost there were no real signs of civilization" (Alhameli, 2004). The discovery of oil in the 1950s has fueled unimaginably fast economic development.

Oil exports began in 1962, and in 1966 Sheikh Zayed became ruler of Abu Dhabi (Bastaki, n.d.). With the 1971 withdrawal of the British from the region, Sheikh Zayed used his political skills to pull seven Gulf emirates together into a federation and become president of the new United Arab Emirates. At that time the UAE had a population of about 180,000 (Bastaki, n.d.); today it has approximately 8.3 million inhabitants (Salama, 2011; UAE Statistics, 2013; UAE Portal, 2013).

Using the country's oil revenues, Sheikh Zayed inspired the development of hospitals, schools and universities as well as unprecedented economic growth. Under the Sheikh's legacy his country prospers and its people enjoy a modern lifestyle their grandparents could never have foreseen. There are challenges, however. The country's infrastructure has been built by imported labor and continues to be largely maintained by expatriates. Emiratis comprise only about 11.5 percent of the UAE population and represent only about 4 percent of the private sector labor market (eGovernment Gateway, 2013; Salama, 2011). 


\section{The Absher Initiative}

In the years since the discovery of oil vaulted UAE's standard of living, its leaders have invested heavily in modernizing the country's economic and social infrastructures while simultaneously working to distribute the benefits of the country's wealth among all of its citizens. Much of the income distribution has been achieved by establishing a relatively large number of high-paying jobs in the public sector. Meanwhile, the country's explosive growth has required the UAE to rely heavily on a skilled and unskilled expatriate workforce.

While laudable in intent, some of UAE's economic policies have to an extent undermined its citizens' incentives to seek private sector employment. The long hours and relatively lower pay afforded by commercial jobs have resulted in low Emirate employment in the private sector (Olson, 2012). Emiratis naturally tend to prefer government jobs because they offer "traditionally high salaries and premium benefits" (Wrigley, 2013).

The Absher Initiative, established in 2012, seeks to enhance Emirati participation in the privatesector labor market in line with principles of UAE Vision 2021 (MOHESR, 2012). One of the initiative's objectives is "training and rehabilitating Emirati workforce," according to a UAE government minister (Sabry, 2013).

UAE universities are expected to play a significant role in supporting Absher initiatives by preparing Emiratis to guide and more fully participate in the nation's development. While many local students represent the first generation of their families to attend college (Shammas, 2011), government leaders express great ambitions for them. The challenge is to balance cultural values with economic needs. "Education is... the means by which [the nation] can build a strong generation, [but the UAE must remain] cautious of adhering to its customs and traditions and able to adjust to the ever-changing needs of our times and to the ever-developing technologies of the modern world," stated Sheikh Zayed's son Sheikh Mohammed Bin Zayed Al Nahyan, Crown Prince of Abu Dhabi (SCO, n.d.).

\section{College of Technological Innovation Meets ZULOs}

Zayed University, one of only two universities in the UAE to achieve American accreditation, was founded for female UAE Nationals in 1998 and began to accept male students in 2010. More than 9,000 are enrolled and while the primary focus is on education of Emirates, students from 19 countries attend. Zayed University's mission is to "prepare students for meaningful and successful twenty-first century personal and professional lives [and] to graduate students who will help shape the future of the region and the world" (ZU Mission, 2013).

To that end Zayed University established the six university-level learning outcomes (dubbed ZULOs) detailed below (ZULO, 2013):

- Critical Thinking and Quantitative Reasoning: ZU graduates will be able to demonstrate competence in understanding, evaluating, and using both qualitative and quantitative information to explore issues, solve problems, and develop informed opinions.

- Global Awareness: ZU graduates will be able to understand and value their own and other cultures, perceiving and reacting to differences from an informed and socially responsible point of view.

- Information Literacy: ZU graduates will be able to find, evaluate and use appropriate information from multiple sources to respond to a variety of needs.

- Language: ZU graduates will be able to communicate effectively in English and Modern Standard Arabic, using the academic and professional conventions of these languages appropriately. 
- Leadership: ZU graduates will be able to undertake leadership roles and responsibilities, interacting effectively with others to accomplish shared goals.

- Technological Literacy: ZU graduates will be able to effectively understand, use, and evaluate technology both ethically and securely in an evolving global society.

We do not claim that the desire to achieve the above learning outcomes is unique to Zayed University. However, as faculty members recently coming from the United States, we were impressed with ZU's efforts to articulate to its students, staff and faculty the importance of achieving these outcomes. The administration established a rigorous process by which the individual colleges and departments created appropriate discipline/major learning outcomes (MALOs) that align with the ZULOs.

The vision statement for the College of Technological Innovation reads, "CTI seeks to produce graduates recognized by business, government and educational institutions in the United Arab Emirates, the Gulf Region, and the rest of the world by offering a sound, modern, and comprehensive education in the innovative application of information technology" (CTI, 2013, p. 4). The college has created six MALOs intended to align with the university's learning outcomes. The CTI MALOs include:

- Critical Thinking and Quantitative Reasoning in IT: Graduates from the College of Technological Innovation will be able to use critical thinking and quantitative processes to identify, analyze, and solve problems and evaluate solutions in an IT context.

- Information Technology Application: Graduates from the College of Technological Innovation will be able to select existing and cutting-edge IT tools and procedures to develop modules and systems.

- Information Technology Management: Graduates from the College of Technological Innovation will be able to assess and determine information resource requirements to develop solutions suitable for IT and business managers operating in a multinational and multicultural environment.

- Information Technology Professional Practice: Graduates from the College of Technological Innovation will be able to work effectively in individual and group situations, understand how groups interact, assume a leadership role when required, and understand the fundamentals of professional and ethical conduct.

- Information Technology Systems Theory and Practice: Graduates from the College of Technological Innovation will be able to understand and communicate the fundamentals of systems theory in the development of appropriate systems that function in a global environment.

- Technical Communication (Bilingual): Graduates from the College of Technological Innovation will be able to express themselves effectively and efficiently in both English and Arabic while using the correct IT terms for each language.

While MALOs do not have a strict one-to-one correspondence with ZULOs, the clear intent is that achieving the college-level learning outcomes will contribute to student achievement of university-level learning outcomes. All CTI course syllabi identify course learning outcomes that are mapped to MALOs.

\section{New Faculty, New Prep, New Approach}

A challenge we see in helping our students attain learning outcomes that pertain to critical thinking and information literacy is that the emphasis necessarily placed on teaching course content can preclude exploratory or unstructured learning activities associated with the development of critical thinking skills. It is a discussion for another essay, but suffice it to note that most college 
textbooks provide more content than can be taught in a semester. Instructors have to decide what can be presented, truly emphasized or safely omitted.

As an instructor who agrees with the fundamental notion that helping college students develop their critical thinking and information literacy skills is as important as the content taught, the first author has struggled with how to balance the need to teach the content while providing opportunities that more directly address the need for our students to develop self-directed learning and critical thinking skills. As Schoen (1991, p. 8) lamented "what aspiring professionals need most to learn, professional schools seem least able to teach."

The opportunity to teach a course on green computing at Zayed University presented a unique opportunity to focus on higher order learning outcomes widely recognized as essential to competing for desirable jobs in the $21^{\text {st }}$ century (Wagner, 2008). Fortuitously, while green computing is a worthwhile and content-rich subject, it can be argued that the much of the content is good-toknow but necessary-to-know for aspiring IT professional. It can be argued that the purpose of such a course is to build awareness of this important and an understanding of how IT-related decisions have environmental consequences rather than create environmental IT engineers.

Green computing addresses business, technological and ethical issues. Beyond the essentials, course content is flexible enough to accommodate a range of student interests. Thus, the first author concluded that the course provided a unique opportunity to encourage development of the ZULOs. The question became, How might one design such a course? The pedagogical approach we selected was problem-based learning (PBL).

\section{Problem-based Learning}

Problem-based learning (PBL) is a pedagogy that puts students at the center of group projects in which they determine to a great extent what they will learn about, and how to find the information or have the experiences they need. As a team, the students share and assess what they already know about a problem, what they need to know, and how to attain knowledge to solve the problem. They gather as a team, then work individually, and reconvene to share, synthesize and report (SGS, 2012). The instructor serves as tutor mentor and critic throughout the process (McLean, Van Wyk, Peters-Futre \& Higgins-Opitz, 2006). While focusing on an aspect of a domain-related challenge that particularly interests them, students working under this paradigm simultaneously have the chance to develop critical thinking and problem-solving strategies.

The PBL format originated in medical education at McMaster University in Canada in 1968 (Taylor \& Miflin, 2008) and has since grown in popularity in other disciplines. It was thought that this approach might prove more memorable, relevant and motivating (Dolmans, Wolfhagen, van der Vleuten \& Wijnen, 2001; Dolmans, De Grave, Wolfhagen \& van der Vleuten, 2005; Schmidt, 2000). Three characteristics are considered essential to PBL: "problems as a stimulus for learning, tutors as facilitators, and group work as stimulus for interaction" (Dolmans et al., 2005, p. 734).

Albanese posited that small-group PBL would meet the five basic human needs of Glasser's control theory (Glasser, 1986; Albanese, 2000): freedom (flexibility), power (to decide their own learning needs), belonging, enjoyment, and survival (success). The constructs identified by control theory align well with Ryan and Deci's Social Determination Theory (SDT) based on their findings that three basic psychological needs similar to Glasser's five - autonomy, relatedness and competence - foster motivation that is more highly internalized (Deci, 1975; Deci \& Ryan, 1985; Ryan \& Deci, 2000; Ryan, Connell \& Deci, 1985). Subsequent research has revealed that internalized or intrinsic motivators have consistently proven more powerful than extrinsic motivators. The most desirable, most productive SDT state is autonomous motivation in which the student learns simply because of finding a subject interesting, important and enjoyable or because 
$\mathrm{s} /$ he recognizes its functional value (Albanese, 2000). Albanese described PBL as offering "a learning climate which promotes autonomous motivators" via educators who consider students' perspectives, give them choices, accord them responsibility, and are "meaningfully involved" (Albanese, 2000, p. 734).

Previous studies have found that learning communities improve skills such as critical thinking and communication abilities (Inkelas \& Weisman, 2003; MacGregor, 1991; Norris \& Barnett, 1994; Pastors, 2006; Saltiel \& Russo, 2001; Schmuck, 1988). While learning communities typically are longer-lasting and/or more intense than the group projects of a single semester-long course, their core commonality is enhanced "interaction of students [fostered] by the intensity and exclusivity [of a] closed membership and impermeable boundary" (Saltiel \& Russo, 2001, p. 3). Numerous studies have shown that [learning community] participants took more responsibility for their own learning and demonstrated greater persistence (Inkelas \& Weisman, 2003; Stassen, 2003; Taylor, 2003; Tinto, Goodsell \& Russo, 1993; Tinto, Goodsell \& Russo, 1994).

While multiple theories have been applied to support problem-based learning, Hamdy pointed out that "PBL was not developed as an enactment of theory" but rather as "an approach to 'good learning practice." The various theoretical explanations may, however, have "facilitated more flexibility in implementation" (Hamdy, 2008, p. 739). Proponents of PBL do not necessarily endorse all variations of the technique (and it does comprise a range of techniques).

Numerous researchers have promoted use of small-group sessions in student-centered settings (Holen, 2000; Dolmans et al., 2001; Eva, 2002). McLean et al. (2006) discussed a setting in which a small-group tutorial initiated a six-week PBL experience and participants subsequently reported positive cognitive, affective and social effects. They reported cooperative learning environments, improved expression in English, developing tolerance and patience, and increased confidence. Qin et al. (1995) had previously linked cooperative (noncompetitive) learning environments with better problem-solving. Schmidt noted a paucity of empirical studies on whether PBL curricula foster SDL but added that those available did support a causal relationship: "Students in these programs tend to spend more self-study time using a greater variety of learning resources, and describe themselves as more intrinsically interested in subject-matter" (Schmidt 2000, pp. 243-244). Norman \& Schmidt (1992) concluded that PBL did appear to enhance self-directed learning skills and transfer of concepts to new problems. Blumberg and Michael (1992) reported a study in which PBL students made more frequent use of the library.

No pedagogical method solves all problems or satisfies all observers. Thus PBL has its detractors and probable deficiencies. Eva in a 2002 commentary questioned the benefits of teamwork, especially claims of synergy. To the extent that the method relies on group or team projects, it can foster parasitism (McLean et al., 2006). Schmidt (2000, p. 243) questioned the degree to which SDL is actually self-directed. He wrote that students working under the SDL paradigm remain assessment-oriented and that "learning in student-centered curricula usually results from a mixture of extrinsically provided cues and intrinsic motivation, rather than from intrinsic motivation alone."

It cannot necessarily be proven that PBL is more effective than some other method (Albanese \& Mitchell, 1993; Hamdy, 2008; Vernon \& Blake, 1993), but longtime users are convinced of its validity. Hamdy (2008) cited years of anecdotal experience, and Norman and Schmidt (2000, p. 727) in their critical review of the technique wrote, "PBL does provide a more challenging, motivating and enjoyable approach to education."

\section{Applying PBL in a Course on Green Computing}

The green computing course is intended to provide students with skills and knowledge needed to assess the impact of computing on the global environment and allow them to assist in developing, 
implementing, and evaluating green computing initiatives. Given the university and college's desired learning outcomes, the course appeared ideally suited to the use of PBL.

However, before committing to using PBL in the classroom, we did consider whether it was an appropriate pedagogical technique to use with Emirati students, as the motivational theories on which PBL draws were developed in the context of "western ideals of democracy, individualism and egalitarianism" (Greveson (2005) cited in Frambach et al. (2012)). We recognized that when exporting a foreign curriculum or pedagogy, "major adaptation and contextualization" may be required (Hamdy, 2008, p. 741). For example, Frambach et al. (2012) examined PBL programs in three medical schools in East Asia, the Middle East, and western Europe. Their study suggested that Middle Eastern students' self-directed learning was challenged by uncertainty and concerns for tradition, hierarchy and achievement. They found that Middle Eastern students "expressed more feelings of uncertainty" (Frambach et al., 2012, p. 742) and attributed this to the contrast between PBL and these students' previous exposure to teacher-centered education and "a culturally determined focus on tradition." The researchers reported that many students initially felt so "lost" they were unable to find the information they needed. They also noted that the students eventually came to accept and appreciate SDL while still finding PBL difficult and continuing to seek more guidance to complete their projects. The authors concluded that cultural factors might adversely affect SDL in PBL settings but that "as students grew used to PBL, SDL skills increased" (Frambach et al., 2012, p. 738).

These concerns aligned with advice that new $\mathrm{ZU}$ faculty received during the orientation provided on their arrival in the UAE. The educational environment of the past four decades has not necessarily helped develop the "innovative" and critically thinking citizen. Emirati students tend to come from "a very prescriptive high school system where rote learning and memorization are the norm." They are not used to independently choosing reading matter and may need context, coaching and repeated examples "of how to study and how to learn" (Shammas, 2011, p. 1). Yet, given the ambitious outcomes identified by the university and the college, we decided give PBL a try.

\section{The Course Design}

The initial course was offered to a gender-segregated class of 39 female Emiratis. The students at Zayed University are used to class sizes of 20 or fewer, and the relatively large number of students posed some class management issues not necessarily associated with the use of PBL. The instructor provided reading assignments, lecture material and videos introducing students to environmental issues:

- Environmental impact associated with the production of ICT and the disposal of resulting e-waste

- Ethical and unethical e-waste recycling practices

- Environmental standards and regulations governing production and disposal of electronic equipment in general

- The relationship between power consumption and carbon footprint/global warming

- Observed and projected environmental impact of global warming

- ICT power consumption and underlying technology and practices resulting in inefficient power use

- Technology and practices used to minimize ICT power consumption

- Examples of how ICT initiatives could be used to reduce an enterprise's carbon footprint by enabling business process redesign

Testing and memorization were minimized, and work on the PBL-based assignment consumed most of the student and instructor effort. 


\section{The PBL Assignment}

Students were formed into teams and requested to consider how to promote green computing in the UAE. Due to faculty-orientation warnings concerning difficulties the students might encounter in formulating research problems, the instructor was willing to offer broad suggestions and allow the students wide latitude in selecting their topics, because a key objective was to get the students to take initiative in determining what they might be most interested in investigating. So, for example, one team decided to examine green building regulations in the UAE while another focused on household energy consumption.

Adapting PBL guidance to the needs of this course, the semester project was divided into four deliverables:

1. Problem/Purpose statement: A host of problems associated with the general subject of green computing, hazardous waste disposal, and energy consumption could be identified. Students were encouraged to explore a variety of issues to get a sense of the type of information they could find and identify the topic that held the most interest for the team. The assignment called for students to research a specific area and provide information to help a targeted audience understand an environmental problem and persuade that audience to participate in mitigating the problem. In essence, the students' challenge was one of informing and persuading. Accordingly, the teams were required to address issues of purpose, scope and appropriate audience in formulating their problem/purpose statements.

2. Knowledge review list: Once the topics were approved, students were directed to formally identify information or knowledge the team already possessed about the topic and identify information gaps. Students were advised to consider their individual interests and capabilities: i.e., how they would best be able to contribute to the team effort.

3. Project plan/Information search strategy: Students were required to submit a formal project plan for creating a wiki report relevant to their project. They were advised to make a tentative outline, a storyboard and a plan to actually create the report. Students had to identify information required to complete their report and plan how to collect that information. Given that all students in the class had some level of exposure to project management principles, they were encouraged to think in terms of identifying deliverables and sub-deliverables, activities required to create the deliverables, and the time and effort commitments needed to execute the activities. Students were given to understand that the process they were engaging in would likely be iterative. As information was collected and learning occurred, they might refine their understanding, reformulate the problem, and reassess their information needs. They also were advised that they would need to be flexible and persistent to schedule and conduct interviews with busy practitioners. Drafts as well as a final submission were required to help ensure that the students were managing project scope and making adequate progress on the assignment. Teams were encouraged by means of extra credit to supplement their online and/or library research with realworld data collection (primarily administering surveys, interviewing experts, and making site visits).

4. Wiki report: Given that building proficiency in the use of technology is identified as a university-level learning outcome, the final report was to be presented in the form of a wiki site. Students were advised that their sites were to be informative, interesting, persuasive, and aesthetically pleasing. Teams were encouraged to exercise their creativity, use multi-media, include links to relevant external sites, and properly cite sources used in preparing the report. Draft online postings allowed the instructor to give feedback before the final wiki report was evaluated. 


\section{Assessment}

The authors prepared an assignment that supported collection of student feedback regarding the course, including: perceived learning, critical assessment of information search strategies, evaluation of findings, synthesis of new knowledge, language use, social interactions, motivation, and enjoyment of the PBL process. These assessment criteria align with discussions of PBL benefits as discussed by McLean et al. (2006), Norman and Schmidt (2000), Qin et al. (1995), and others.

\section{Results to Date}

Unfortunately, we have not been able to complete analysis of the student feedback received.

So far student response has been good, and class assignment "deliverables" impressive. For example, as mentioned in the initial assignment, students were advised they might have to be persistent to obtain the access to people and information they had decided they needed. Such events did occur, and the authors were pleased to note that the students required minimal assistance as they adjusted the execution of their project plans.

\section{Conclusions}

This paper is an interim report on an innovation-in-practice. The results of student evaluations received on the first offering of this course were very positive and prompted the author to apply the technique in a subsequent offering of the course. However, as we have not been able to rigorously analyze and report the feedback received we lack the evidence to support our positive assessment of the technique. We believe that the PBL method has yielded a positive effect the teaching context described above.

\section{References}

Abu Dhabi eGovernment Gateway. (2013). Abu Dhabi eGovernment .Retrieved from https://www.abudhabi.ae/egovPoolPortal_WAR/appmanager/ADeGP/Citizen?_nfpb=true\&_pageLabel $=\mathrm{p} 20160 \& \mathrm{did}=254196 \&$ lang $=$ en

ACRL. (2013). Information Literacy Competency Standards for Higher Education. Retrieved 1 December 2013, from Association of College and Research Libraries: http://www.ala.org/acrl/standards/informationliteracycompetency

Albanese, M. (2000). Problem-based learning: Why curricula are likely to show little effect on knowledge and clinical skills. Medical Education, 34, 729-738.

Albanese, M., \& Mitchell, S. (1993). Problem-based learning: A review of literature on its outcomes and implementation issues. Academic Medicine, 68(1), 52-81.

Alhameli, M. S. (2004, 18 October). Images are an outstanding evidence on rapid development: A perfect example from United Arab Emirates (UAE). Retrieved 15 December 2013, from International Society for Photogrammetry and Remote Sensing: http://www.isprs.org/proceedings/XXXV/congress/comm2/papers/177.pdf

Bastaki, E. M. (n.d.). H.H. Sheikh Zayed bin Sultan Al Nahyan: President of the United Arab Emirates. Retrieved 11 December 2013, from United Arab Emirates University: http://faculty.uaeu.ac.ae/ eesa/History/zayed.html

Beachboard, M. R. \& Beachboard, J. C. (2010). Critical thinking pedagogy and student perceptions of university contributions to their academic development. Informing Science: The International Journal of an Emerging Transdiscipline, 13, 53-71. Retrieved from http://www.inform.nu/Articles/Vol13/ISJv13p053-071Beachboard548.pdf 
Beachboard, M. R., Beachboard, J. C., Li, W., \& Adkison, S. R. (2011). Cohorts and relatedness: Selfdetermination theory as an explanation of how learning communities affect educational outcomes. Research in Higher Education.

Blumberg, P., \& Michael, J. (1992). Development of self-directed learning behaviors in a partially teacherdirected problem-based learning curriculum. Teaching and Learning in Medicine: An International Journal, 4(1), 3-8.

Deci, E. L. (1975). Intrinsic motivation. New York: Plenum Press.

Deci, E. L., \& Ryan, R. M. (1985). Intrinsic motivation and self-determination in human behavior. New York: Plenum Press.

Dolmans, D., De Grave, W., Wolfhagen, I., \& van der Vleuten, C. (2005). Problem-based learning: Future challenges for educational practice and research. Medical Education, 39, 732-741.

Dolmans, D., Wolfhagen, I., van der Vleuten, C., \& Wijnen, W. (2001). Solving problems with group work in problem-based learning: Hold on to the philosophy. Medical Education, 35, 884-889.

Eva, K. W. (2002). Teamwork during education: The whole is not always greater than the sum of the parts. Medical Education, 36, 314-316.

Frambach, J. M., Driessen, E. W., Chan, L.-C., \& van der Vleuten, C. (2012). Rethinking the globalisation of problem-based learning: How culture challenges self-directed learning. Medical Education, 46, 738747.

Glasser, W. (1986). Control theory in the classroom. New York: Harper and Row.

Greveson, G., \& Spencer, J. (2005). Self-directed learning: The importance of concepts and contexts. Medical Education, 39(4), 348-349.

Hamdy, H. (2008). The fuzzy world of problem based learning. Medical Teacher, 30, 739-741.

Holen, A. (2000). The PBL Group: Self-reflections and feedback for improved learning and growth. Medical Teacher, 22(5).

Inkelas, K. K., \& Weisman, J. L. (2003). Different by design: An examination of student outcomes among participants in three types of living-learning programs. Journal of College Student Development, 44(3), 335-368.

Jieun Wrigley (interviewer). (2013, 12 May). ENDP discuss why the government will actually be paying some Emiratis to join the private sector [Emirates 24/7 video]. Dubai One TV.

Landsberger, H. A. (1958). Hawthorne revisited. Ithaca: Cornell University.

MacGregor, J. (1991). What differences do learning communities make? Washington Center News, 6, 4-9.

McLean, M., Van Wyk, J. M., Peters-Futre, E. M., \& Higgins-Opitz, S. B. (2006). The small group in problem-based learning: More than a cognitive 'learning' experience for first-year medical students in a diverse population. Medical Teacher, 28(4), e94-e103.

Methodology of estimating the population in UAE. (n.d.). United Arab Emirates, National Bureau of Statistics. Retrieved 1 December 2013, from http://www.uaestatistics.gov.ae/ReportPDF/Population\%20Estimates\%202006\%20-\%202010.pdf

Ministry of Higher Education and Scientific Research. (2012). Absher Initiative. Retrieved from http://www.mohesr.gov.ae/En/Pages/Absher.aspx

Norman, G. R., \& Schmidt, H. G. (1992). The psychological basis of problem-based learning: A review of the evidence. Academic Medicine, 67(9), 557-565.

Norman, G. R., \& Schmidt, H. G. (2000). Effectiveness of problem-based learning curricula: Theory, practice and paper darts. Medical Education, 34, 721-728. 
Norris, C. J., \& Barnett, B. (1994, 28-30 October). Cultivating a new leadership paradigm: From cohorts to communities. Annual Meeting of the University Council for Educational Administration, Philadelphia, PA.

Olson, M.-L. (2012, 8 May). Freeze "government employment of Emiratis." The National, UAE. Retrieved 1 December 2013, from http://www.thenational.ae/news/uae-news/freeze-government-employment-ofemiratis

Pastors, C. R. (2006, May/June). Assessing a learning community program through a student survey. Assessment Update, 18(3), 1-8.

Problem-Based Learning. (n.d.). Study Guides and Strategies. Cooperative Learning Series. Retrieved 11 December 2013, from http://www.studygs.net/pbl.htm

Qin, Z., Johnson, D., \& Johnson, R. (1995). Cooperative vs. competitive efforts and problem solving. Review of Educational Research, 65, 129-143.

Ryan, R. M., Connell, J., \& Deci, E. L. (1985). A motivational analysis of self-determination and selfregulation. In C. Ames \& R. Ames (Eds.), Research on motivation in education (pp. 13-51). New York: Academic Press.

Ryan, R. M., \& Deci, E. L. (2000). Self-determination theory and the facilitation of intrinsic motivation, social development, and well-being. American Psychologist, 55(1), 68-78.

Sabry, S. (2013, 2 April). Absher Initiative begins first phase of strategy for 2013. Gulf News, UAE | Employment]. Retrieved 1 December 2013, from http://gulfnews.com/news/gulf/uae/employment/absherinitiative-begins-first-phase-of-strategy-for-2013-1.1165992

Salama, S. (2011, 5 April). Influx of foreigners spikes UAE population to $8.3 \mathrm{~m}$. Gulf News, UAE | General. Retrieved 1 December 2013, from http://gulfnews.com/news/gulf/uae/general/influx-of-foreignersspikes-uae-population-to-8-3m-1.787518

Saltiel, I. M., \& Russo, C. S. (2001). Cohort programming and learning: Improving educational experiences for adult learners. Malabar, FL: Krieger.

Schmidt, H. (2000). Assumptions underlying self-directed learning may be false. Medical Education, 34(4), 243-245.

Schmuck, P. (1988). Preparing superintendents for the unexpected, the unanticipated and the untoward. ERIC Document Reproduction Service No. ED 309548.

Schoen, D. (1991). Educating the reflective practitioner: Toward a new design for teaching and learning. San Francisco: Jossey-Bass.

SCO - The Scholarship Co-ordination Office, Abu Dhabi, UAE. (n.d.). The Distinguished Student Scholarships of H.H. The President. Retrieved 22 December 2013, from http://www.pso.ae/quotes.htm

The Seven Emirates. (n.d.). Retrieved 1 December 2013, from Government.ae: The Official Portal of the United Arab Emirates http://www.government.ae/en/web/guest/seven-emirates;jsessionid=5Ac7udqhydqdYBmiXoVGXvr.undefined

Shammas, N. (2011, 12 January). Observations about teaching Emirati women. Academia.edu. Retrieved 1 December 2013, from http://www.academia.edu/4405930/Observations_about Teaching_Emirati_Women_SHAMMAS 2010

Stassen, M. L. A. (2003, October). Student outcomes: The impact of varying living-learning community models. Research in Higher Education, 44(5), 581-613.

Taylor, D., \& Miflin, B. (2008, 1 March). Problem-based learning: Where are we now? (Tech. Rep. No. 30, pp. 742-763). London, UK: Association for Medical Education in Europe.

Taylor, P. (2003, 23 June). Epic: Blended knowledge and learning solutions. Epic Performance Improvement Limited. Retrieved 9 February 2007, from http://www.epic.co.uk/content/news/archive/2003/news_stories_2003/ns_230603_01.html. 
Tinto, V., Goodsell, A., \& Russo, P. (1993). Building community. Liberal Education, 79(4), 16-21.

Tinto, V., Goodsell, A., \& Russo, P. (1994). Building learning communities for new college students: A publication of the National Center on Postsecondary Teaching, Learning and Assessment, Pennsylvania State University. Liberal Education, 79(4), 16-21.

UAE History: Our Sheikh Zayed. (n.d.). UAE National Center for Documentation and Research. Retrieved 1 December 2013 from http://www.cdr.gov.ae/ncdr/English/uaeGuide/PrintSheikh.aspx

Vernon, D., \& Blake, R. (1993). Does problem-based learning work? A meta-analysis of evaluative research. Academic Medicine, 68(7), 550-563.

Wagner, T. (2008). Rigor redefined. Educational Learning, 66(2), 20-25.

Zayed University. (2013). About the university (The Mission). Retrieved 1 December 2013, from Zayed University, UAE: http://www.zu.ac.ae/main/en/explore_zu/index.aspx

Zayed University College of Technological Innovation. (2013). College of Technological Innovation. Retrieved from http://www.zu.ac.ae/main/files/images/colleges publications/collegeBooks2013/ZU CIT.pdf

Zayed University. (2013). Zayed University Learning Outcomes (ZULOS). Retrieved 1 December 2013, from Zayed University, UAE: http://www.zu.ac.ae/main/en/explore_zu/index.aspx.

\section{Biographies}

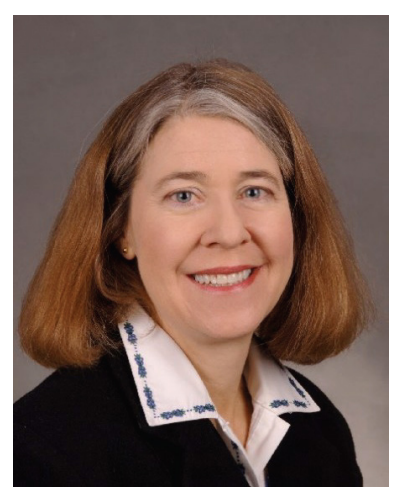

Martine Robinson Beachboard is an Associate Professor of Mass Communication at Idaho State University, USA. She teaches courses in advertising, public relations, journalism, writing, and mass communication and society. Dr. Beachboard previously taught with the University of Maryland European Division. She has published in the areas of international and intercultural journalism. Her research has appeared in Research in Higher Education and in the Journal of Advertising Education. Her professional career experience was in journalism and university public relations. She is a member of the Association for Education in Journalism and Mass Communication (AEJMC) and the American Advertising Federation. She regularly advises students participating in the AAF National Student Advertising Competition.

John C. Beachboard is a Professor of Computer Information Technology at the Zayed Universi-

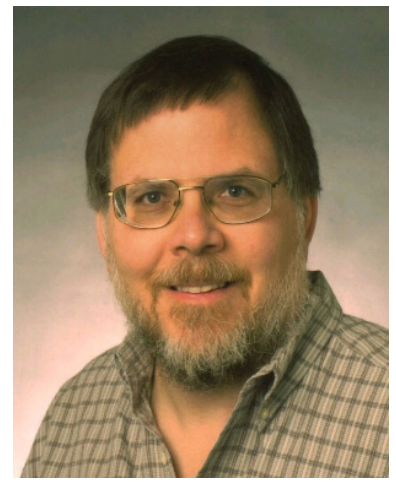
ty College of Technological Information in Abu Dhabi, UAE. Previously he was a professor of Computer Information Systems at Idaho State University, USA. He has more than 25 years' experience implementing large-scale information technology and telecommunications systems and directing the US Army's Data Network Control Center in Europe. He received an AIS Award for Innovation in IS Education for his work incorporating IT service management concepts in the CIS curriculum at ISU. He is the author of Peeling the Onion: IT Governance and Management for Business Managers. Dr. Beachboard's teaching and research interests emphasize practical approaches for delivering and operating secure, cost-effective IT services. 